\title{
The Probability Prediction Model of Motorcyclist Accident Against IRSMS and AIS from the Police Department, East Java (A Case Study in Kediri Regency and Surabaya City)
}

\author{
Muhammad Zainul Arifin \\ Civil Engineering Department \\ Brawijaya University \\ Malang, Indonesia \\ mzaub@ub.ac.id
}

\author{
Achmad Wicaksono \\ Civil Engineering Department \\ Brawijaya University \\ Malang, Indonesia \\ wicaksono1968@yahoo.com
}

\begin{abstract}
According to traffic accident data collected by the East Java Police Department through IRSMS and AIS portal in 2018, the number of accidents tended to incline from 2015 to 2017. The objective of this research focusing on Kediri and Surabaya area is finding the characteristic of motorcycle riders in the study locations, looking for the characteristic of motorcycle-related accidents in both cities, and creating a motorcycle-related accident probability model in the targeted cities. The primary data was obtained using questionnaires and interview with 200 participants. The analysis method used in this research was descriptive frequency analysis and logistic regression analysis. The result of the descriptive analysis shows that 112 respondents has been in a traffic accident before. Based on the social economy characteristic, riders aged under $25(50 \%)$ are the biggest group. Also, based on the motorcycle movement aspects, the most influential group was the one with more than $5 \mathrm{~km}$ mileage a day $(68 \%)$. While based on logistic regression analysis, it resulted that the influencing factor are $\mathrm{X} 2$ (ages) and X12 (mileage of travel). Overall, the probability of motorcycle-related accident probability of riders under 25 whose mileage more than $5 \mathrm{~km}$ a day is $91.5 \%$.
\end{abstract}

Keywords: model, motorcyclist related accident, Kediri, Surabaya, Model Logistic Regression

\section{INTRODUCTION}

Transportation is vital in the trade, community, and government systems. A country can advance because of adequate and easily accessible transportation access. The role of transportation in community life is huge as access to the goods and services distribution. It distributes from the origin place to a particular destination. It supports economic, social and cultural life in the community. Furthermore, the higher birth rate encourages the high demand for transportation. Therefore, it is essential in every aspect.

Developed countries always face transportation problems and also by developing countries such as Indonesia, both in urban and inter-city transportation. Area development encourages economic improvement. Therefore, the mobility of goods and people increases rapidly. It also affects the higher traffic movement in the area.

The motorcycle is considered as a primary needs in Indonesia, including the middle to the lower class of society.
Besides, the motorcycle provides efficiency even in traffic jams and low costs. Motorcycle ownership is continually increasing. It due to public transportation have not been able to be on time and the increase in fuel.

East Java is the largest province in the Java island within $47,800 \mathrm{~km}^{2}$ of area. Therefore, mobility is very high in East Java.

The distribution needs of goods and services must be distributed properly to all cities in East Java. Kediri Regency is the largest areas in East Java, has a 1,386 km2 of the area within 1,554,385 of residents [1]. Meanwhile, Surabaya is a capital city of East Java Province within $326.81 \mathrm{~km}^{2}$ of area.

Integrated Road Safety Management System (IRSMS) or Accident Information System (AIS) or Accident Information System is an online site of the Indonesian National Police Traffic Corps (KORLANTAS POLRI). It provides various information about safety, accident statistics, and accident case and road safety. It provides reliable and verifiable data, including the accident database and integrated analysis of the road traffic system. Information about the accident area is the basis for all interventions. According to accident data from IRSMS and AIS, Kediri Regency has third ranks. It has the highest number of motorcycle accidents and the first number of motorcycle accidents in East Java. Whereas, Surabaya city is a metropolitan city and has a high transportation activity compared to transportation activities in other cities in East Java [2].

\section{A. Purpose}

The purpose of in this study are:

- Knowing the characteristics of motorcycle riders in Kediri Regency and Surabaya City.

- Knowing the characteristics of motorcycle accidents in Kediri Regency and Surabaya City.

- Making the model of motorcycle accident opportunities in Kediri Regency and Surabaya City. 


\section{METHODS} Fig. 1.

The steps in this study was arranged as in the following

\section{A. Variables}

Response variable (y) was used to determine the opportunity of motorcycle rider toward an accident. While the explanatory variables (x) were socio-economic aspects, movement, and behaviour. The indicators of the explanatory variables as follows [3]:

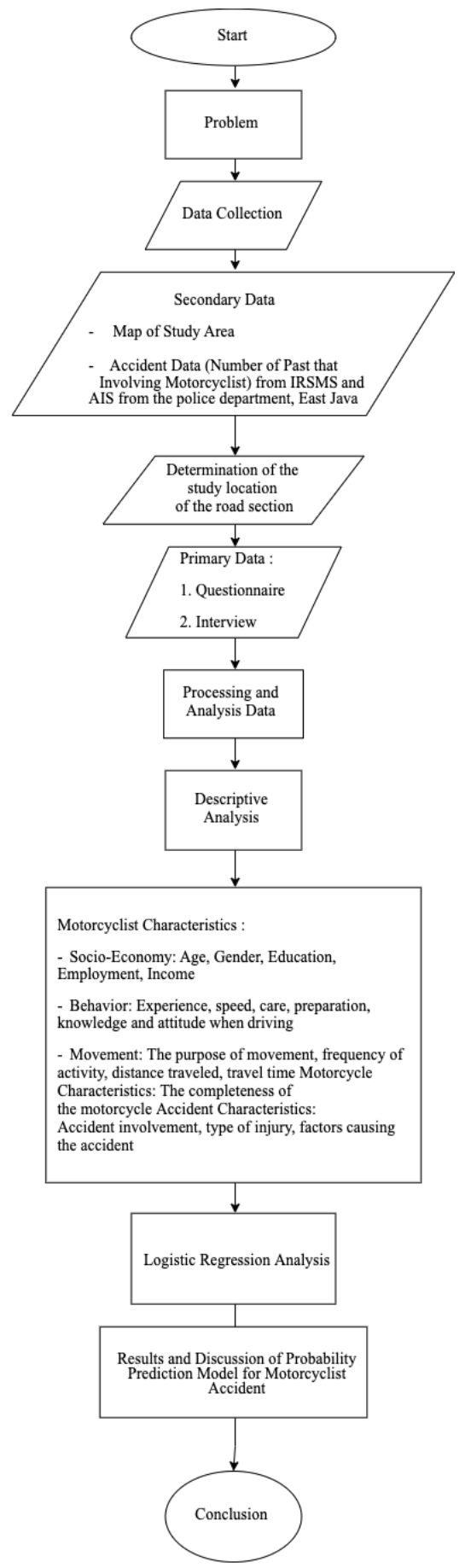

Fig. 1. Flowchart Research.
1) Socio-Economic aspects: age, sex, education, occupation, income, motorcycle ownership, number of ownership, and other vehicles owned.

2) Aspects of Movement: purpose of movement, travel time, travel distance, the intensity of using motorcycle, time to start activities.

3) Behavioural aspects: the attitude before driving and the attitude when riding on a motorcycle.

\section{B. Data Analysis}

1) Descriptive Analysis: Descriptive analysis is an analysis to describes a situation or event. It is only limited to describe facts. The characteristics of motorcycle riders were analyzed including the characteristics of the movement, socio-economic, and behavioral. The frequency analysis was performed in this study.

2) Analysis of Logistic Regression: In this study, an accident model was developed to determine the motorcycle accident by the rider characteristics, the accident characteristics, as well as the geometric characteristics of the existing road. The accident chance was analysed by the logistic regression method. It due to the multivariate normal distribution cannot be fulfilled. The combination of continuous and category variables was used as the explanatory variables. Logistic Regression was performed because the likelihood value was in the range $0-1$. It distinguished between the logistic regression method from linear regression. The value of the response variable was $<0$ or $>1$ in the ordinary linear regression.

The structure of the probability prediction model for motorcyclist accident as follows [4]:

$P(B A)=1 /\left(1+e^{\wedge}\left(-\left(\beta_{0}+\beta_{1} X_{1}+\beta_{0}+\beta_{2} X_{2}+\beta_{0}+\beta_{3} X_{3}+\ldots\right)\right)\right)$

Where:

$\mathrm{P}_{(\mathrm{BA})}=$ The chance of a bicycle accident

e $\quad=$ natural number (2.71828)

$\beta=$ coefficient of the explanatory variable (predictor)

$\mathrm{X}=$ explanatory variable (predictor)

\section{Sample}

The time linear method was used to determine the samples number. The time linear method compared to other methods has the advantage such as a more specific and detailed assessment. The following is the sample calculation formula using the time linear function method [5]:

$$
n=\left(T-t_{0}\right) / t_{1}
$$

Where:
$\mathrm{n}=$ Minimum number of samples Purpose
$\mathrm{T}=$ Time available for research
$\mathrm{t}_{0}=$ Sampling time
$t_{1}=$ Time for the respondent to fill in the questionnaire. 
Within 10 days study $(10 \times 24$ hours $=240$ hours $/ 10$ days), the survey time was 6 hours ( 6 hours / day x 10 days $=60$ hours $/ 10$ days $)$, and the time required for each sampling was 0.25 hours $(0.25$ hours / day x 10 days $=2.5$ hours / 10 days). Therefore, the minimum samples number was 100 respondents in each city.

\section{RESULTS AND DisCUSSION}

\section{A. Descriptive Analysis}

1) The Characteristics of Socio-Economic: In this study, the majority of motorcycle riders were male $(82 \%)$, aged $15-25$ years $(46 \%)$, educational background was high school (50.5\%) and student (36.5\%). While the income was more than 5.000.000 IDR (36\%) and the majority had a motorcycle $(52.5 \%)$.

2) The Characteristics of Movement: In this study, motorcycle riders was intended for their movements to work $(51 \%)$, distance for travel $<5 \mathrm{~km}(31.5 \%)$ with $30-60$ minutes of travel time $(52.5 \%)$ and the use of motorcycle $(76.5 \%)$.

3) The Characteristics of Behavior: Behaviour of motorcycle riders was determined before driving and when driving. Before driving they check the lights condition $(45 \%)$, the brakes condition $(37 \%)$, and the tires condition $(38 \%)$. When riding a motorcycle, respondents always wear helmets $(51.5 \%)$, riding together $(71 \%)$ and running from red lights $(37.5 \%)$.

\section{B. The probability prediction model of accident toward motorcycle rider at the study site}

Prediction models of accident opportunities toward motorcycle rider in Kediri Regency as follows:

$P(B A)=1 /\left(1+e^{\wedge}\left(-\left(-0.292+1.966 X_{1}-0.499 X_{12}+0.446 X_{13}\right.\right.\right.$

$\left.\left.\left.-1.597 X_{25}+0.127 X_{26}\right)\right)\right)$

Where:

$\mathrm{X}_{1}=$ Gender,

$\mathrm{X}_{12}=$ Distance,

$\mathrm{X}_{13}=$ Intent of movement,

$\mathrm{X}_{25}=$ Check of brake condition,

$\mathrm{X}_{26}=$ Check of tire condition.

According to the merging model, it indicates that female riders do not check the brakes condition and the tires condition before driving. They ride for work with distance less than $5 \mathrm{~km}$.

The probability prediction model for accident in the city of Surabaya as follows:

$P\left(X_{i}\right)=1 /\left(1+e^{\wedge}\left(-\left(13.702+0.930 X_{1}+0.518 X_{3}-3.386 X_{12}\right.\right.\right.$ - $\left.\left.\left.2.412 X_{46}-0.988 X_{54}+3.586 X_{55}\right)\right)\right)$

Where:

$\mathrm{X}_{1}=$ Gender

$\mathrm{X}_{3}=$ Education
$\mathrm{X}_{12}=$ Frequency of motorcycle use

$\mathrm{X}_{46}=\mathrm{Go}$ ahead from the right

$\mathrm{X}_{54}=$ Time for motorcycle driving

$\mathrm{X}_{55}=$ Causes of accidents

The accident chance model in the Surabaya city is influenced by the gender and educational background. In addition, the behaviour of motorcycle riders, such as overtaking vehicles from the left provides an opportunity toward accidents.

\section{CONCLUSIONS}

Respondents had an accident $69 \%$ in Kediri, and 52\% in Surabaya. The accident case in Kediri occurred during the day with a percentage of $34.8 \%$. The majority of accidents at night with a percentage of $43 \%$ in the Surabaya city. The motorcycle accidents was caused by slippery or damaged road conditions $(36.2 \%)$ in Kediri, while in the Surabaya City was caused by their own mistakes such as drowsiness, unfocused, and joking (33\%).

The prediction model of accident chance toward motorcycle riders in this study location as follows:

$$
P_{(X i)}=1 /\left(1+e^{\wedge}\left(-\left(1,395-1,208 X_{2}+0,987 X_{12}\right)\right)\right)
$$

Where:

$\mathrm{X}_{2}=$ Age,

$\mathrm{X}_{12}=$ Distance for motorcycle riders under 25 years old.

Distance more than $5 \mathrm{~km}$ has the potential to have an accident of $91.5 \%$.

\section{ACKNOWLEDGMENT}

We sincerely thank to Ismawan Adhi Ramadhan and Akbartino Jihadagama who helped for collecting data.

\section{REFERENCES}

[1] Statistic , Kediri Regency in Figures. Kediri, 2018.

[2] Polda East Java, Traffic Accident Data : http://korlantas.info, 2018.

[3] Sari and Endang S, Audience Research, Jakarta: Ghalia Indonesia, 1999.

[4] Sulistio, Harnen, et al. Motorcycle Accident Model On A Road Malang: Universitas Brawijaya, 2010.

[5] Tamin, Ofyar Z, Transport Planning and Modelling. Bandung: ITB Bandung, 2000 